\title{
Cross-Coupling Reaction of Organotellurides with Grignard Compounds Catalyzed by $\mathrm{MnCl}_{2} / \mathrm{Cul}$
}

\author{
Márcio S. Silva*; Renan S. Ferrarini; Bruno A. Souza; Rogério A. Gariani; Fabiano T. \\ Toledo; João V. Comasseto
}

University of São Paulo, Brazil

*e-mail: marciosasi@usp.br

Keywords: Organotellurides, Manganese Chloride, Cross-Coupling Reaction

\section{INTRODUCTION}

Vinylic tellurides are useful intermediates in organic synthesis. ${ }^{1}$ These compounds have been employed for carbon-carbon bond formation by reaction with organometallics catalyzed by $\mathrm{Pd}, \mathrm{Ni}$ and Fe species. ${ }^{1 \mathrm{~b}}$ In this work, we describe the use of $\mathrm{MnCl}_{2} / \mathrm{Cul}$ as catalysts to promote the coupling reaction of Grignard reagents 1 with vinylic tellurides 2 (Scheme 1).

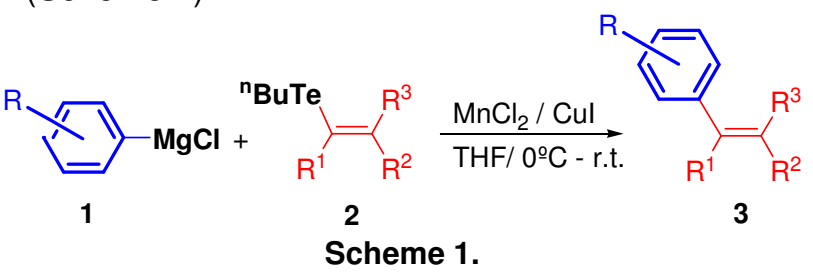

\section{RESULTS AND DISCUSSION}

The vinylic telluride (2a) and phenyl magnesium chloride (1a) were employed as model compounds to determine the best reaction conditions. The use of $\mathrm{MnCl}_{2}(20 \mathrm{~mol} \%)$ or Cul (20 mol \%) alone promotes the cross-coupling reaction in low yield $(10 \%$ and 30 $\%$ respectively). When a mixture of $\mathrm{MnCl}_{2} / \mathrm{Cul}(20 / 20$ or $10 / 10 \mathrm{~mol} \%)$ was used, the homo-coupling reaction of the Grignard reagent (1a) was observed. This side reaction was suppressed by using $5 \mathrm{~mol} \%$ of each metal salt $\left(\mathrm{MnCl}_{2} / \mathrm{Cul}\right)$. Under this conditions the product $(\mathbf{3 a})$ was obtained in $78 \%$ yield. As can be observed in Scheme 2 an inversion of the olefin configuration was observed. The above conditions were employed to promote the cross-coupling of others Grignard reagents $\mathbf{1}$ and vinylic tellurides 2 giving the products in $50-79 \%$ yields as can be observed in Scheme 3.

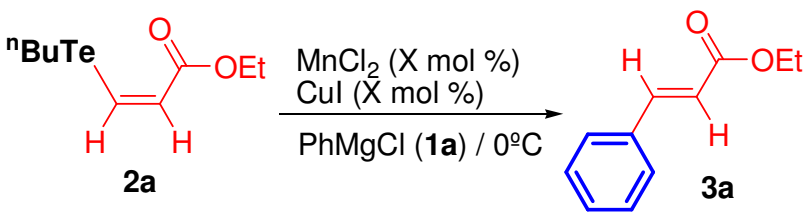

Scheme 2.<smiles>CC1(C)CC(=O)C=C(c2ccccc2)C1</smiles><smiles>CCOCCN(/C=C\c1ccccc1)/C=C\c1ccccc1</smiles>

3a / $60 \%$

3b / $79 \%$<smiles>COc1nc(OC)nc(-c2ccccc2)n1</smiles><smiles>[OH2+]CCC#C/C=C\c1ccccc1</smiles><smiles>CCOC(=O)/C(=C\c1ccccc1)C(O)c1ccccc1</smiles>

$3 e / 60 \%$<smiles>CCOC(=O)C(=C(C)c1ccccc1)C(O)c1ccccc1</smiles>

3f / $50 \%$

$3 d / 52 \%$<smiles>CCOC(=O)C(=C(C)c1ccc(F)cc1)C(O)c1ccccc1</smiles>

$3 g / 54 \%$

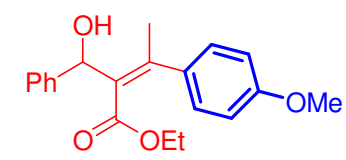

$3 h / 69 \%$
Scheme 3.

\section{CONCLUSION}

We have developed an efficient catalytic procedure to cross-coupling Grignard reagents with vinylic tellurides using $\mathrm{MnCl}_{2} / \mathrm{Cul}$ as the catalysts.

\section{ACKNOWLEDGEMENTS}

The authors acknowledge the following agencies for support: CNPq and FAPESP.

\section{REFERENCES}

1 a) Zeni, G.; Braga, A. L.; Panatieri, R. B.; Lüdtke, D. S. Chem. Rev. 2006 106, 1032-1076; b) Zeni, G.; Braga, A. L.; Stefani, H. A. Acc. Chem. Res. 2003, 36, 731-738. 